\title{
Gamma spectroscopy analysis of produced water from selected flow stations in delta state, Nigeria
}

\author{
Avwiri Gregory O. ${ }^{1}$, Esi Emmanuel ${ }^{1}$, Agbalagba Ezekiel O. ${ }^{2}$ \\ ${ }^{1}$ Department of Physics, University of Port Harcourt, Choba, Rivers State, Nigeria \\ ${ }^{2}$ Department of Physics, Federal University of Petroleum Resources, Effurun, Nigeria
}

Email address:

gregory.avwiri@uniport.edu.ng(Avwiri G. O.), esiemmanuel@yahoo.com(Esi E. O.), ezek64@yahoo.com(Agbalagba E. O.)

To cite this article:

Avwiri Gregory O., Esi Emmanuel, Agbalagba Ezekiel O.. Gamma Spectroscopy Analysis of Produced Water from Selected Flow Stations in Delta State, Nigeria. International Journal of Environmental Monitoring and Analysis. Vol. 1, No. 5, 2013 , pp. 167-174. doi: 10.11648/j.ijema.20130105.11

\begin{abstract}
This paper present the findings of naturally occurring radionuclides $\left({ }^{226} \mathrm{Ra},{ }^{228} \mathrm{Ra}\right.$ and $\left.{ }^{40} \mathrm{~K}\right)$ carried out on produced water collected from seven oil and gas fields onshore of Delta State, using gamma spectroscopy. Twenty- one produced water samples from seven flow stations waste pit were collected within the oil fields using standard methods. The average specific activity concentrations for the radionuclides ${ }^{40} \mathrm{~K},{ }^{226} \mathrm{Ra}$ and ${ }^{228} \mathrm{Ra}$ are $48.78 \pm 13.67 \mathrm{Bql}^{-1}, 6.04 \pm 2.48 \mathrm{Bql}{ }^{-1}$ and $5.18 \pm 2.14 \mathrm{~Bq}^{-1}$ respectively. These obtained values are higher than the WHO, 2008 recommended standard limit of $10 \mathrm{~Bq}^{-1}$, $1.0 \mathrm{Bql}^{-1}$ and $0.1 \mathrm{Bql}^{-1}$ for ${ }^{40} \mathrm{~K},{ }^{226} \mathrm{Ra}$ and ${ }^{228} \mathrm{Ra}$ respectively. Radium equivalent have average activity concentration of $14.36 \pm 5.55 \mathrm{Bql}^{-1}$ while the average absorbed dose rate of $6.68 \mathrm{mSvy}^{-1}$ was found to be higher than the UNSCEAR 2000 acceptable standard of $1.5 \mathrm{mSvy}^{-1}$. Although the hazard indices $\left(\mathrm{H}_{\mathrm{ex}}, \mathrm{H}_{\mathrm{in}}\right)$ calculated are still within their tolerable levels, the estimated committed effective dose due to intake of the sampled water for all the produced water considered are far above the ICRP $0.1 \mathrm{mSvyr}^{-1}$ maximum permissible limit. The result indicates some level of water pollution in the studied water samples. This work will add to the world data base of natural radionuclide in produced water from crude oil.
\end{abstract}

Keywords: Natural Radioactivity, Produced Water, Oil Fields, Delta State

\section{Introduction}

During oil exploitation large amounts of water accompany the production stream. This water is usually referred to as produced water, formation water or oilfield brine (Neff, 2002). This water may be formation water trapped within the reservoir for millions of years, or a mixture of seawater and formation water, when seawater has been injected in order to maintain pressure in the reservoir during oil and gas production (Gafvert. and Faerevik, 2004).

Produced water is the highest volume waste generated in association with oil and gas production operations. Despite treatment before discharge to satisfy regulatory limitations on oil content, produced water contains a certain amount of Naturally Occurring Radioactive Materials (NORM) such as ${ }^{226} \mathrm{Ra}$ and ${ }^{228} \mathrm{Ra}$. NORM are difficult to remove from produced water, which make the assessment of their effects on human health important to the oil and gas producing industries.

One component that has become the subject of much attention is naturally occurring radioactive elements, foremost radium, which may be present in the produced water. Four radium isotopes exist in nature $\left(^{226} \mathrm{Ra}\right.$ from the uranium decay series, ${ }^{228} \mathrm{Ra}$ and ${ }^{224} \mathrm{Ra}$ from the thorium decay series, and ${ }^{223} \mathrm{Ra}$ from the actinium decay series) where ${ }^{226} \mathrm{Ra}$ and ${ }^{228} \mathrm{Ra}$ are the most long-lived, with physical half-lives of 1600 and 5.75 years, respectively (IAEA, 2003; Chowdhury et al., 2004). Radium enters the water from the surrounding rocks by direct alpha recoil into the water or chemical leaching (the latter may be facilitated by crystalline damage caused by recoil energy from previous alpha decays in the decay series). Due to their short half-lives, ${ }^{223} \mathrm{Ra}$ and ${ }^{224} \mathrm{Ra}$ do not play a significant role in risk assessment. The high temperature and pressure in the oil reservoirs also aid in the leaching of radium from reservoir rock into the formation water. Produced water may contain radium components in addition to metals, polycyclic aromatic hydrocarbons, volatile organic carbons process chemicals. Two isotopes of radium, ${ }^{226} \mathrm{Ra}$ and ${ }^{228} \mathrm{Ra}$ are of most concern as they are leachable and mobile because of their high solubility in water (Vegueria et al; 2002). Radium isotopes probably make up the bulk of 
nuclide activity in produced water. The isotope ${ }^{226} \mathrm{Ra}$ emits mostly alpha particles and a small amount of gamma rays as whereas ${ }^{228} \mathrm{Ra}$ emits beta particles (Neff 2002).

The essence of this gamma spectroscopy analysis is to ensure that the reference dose level (RDL) of committed effective dose of $0.1 \mathrm{mSvy}^{-1}$ in drinking water is not exceeded in any studied produced water since most of these water are not pre-treated or treated before discharging into the surface water body and the environment by the operating companies. Moreso, having established in earlier study that gross alpha and beta activities concentration were exceeded in drinking waters from some of the oil producing areas in Delta State (Agbalagba and Avwiri, 2012), the need for the specific activity evaluation in these oil fields produce water sources arose and this lend credence to this study. This is to ascertain the safety of produced water disposal, surface and ground water for drinking before the eventual handover of the oil blocks to the new operators.

\section{Materials and Methods}

\subsection{Description of Study Area}

This study was carried out within the Oil Mining Leases $26 \& 30$ (OMLs 26 \& 30) in Delta state, onshore Western Niger delta of Nigeria. The study area lies within latitude $5^{0} 18 " \mathrm{~N}$ and $5^{0} 68^{\prime \prime} \mathrm{N}$ and longitude $5^{0} 33$ "E and $6^{0} 40^{\prime \prime} \mathrm{E}$ South-West of Niger delta region of Nigeria. The geology of the study area has been reported earlier (Taiwo and Akalia, 2009). The lithological log correlation showed that the topsoil layer, which is composed of plastic clay, has a thickness ranging from $30 \mathrm{ft}-35 \mathrm{ft}$, which is capable of protecting the underlain aquifer unit from being contaminated by surface toxic discharge. A silty sand/sandy layer directly underlies this, which form the aquifer unit of the study area. The groundwater table ranges between $8 \mathrm{ft}-$ $10 \mathrm{ft}$. The natural water system of the area depending on the location and depth and belong to two extremes of fresh and salt water with an intermediary represented by the blackish water (SPDC, EIA, 2004). Thus there is the likelihood of overflowing of this produced water from their waste pits, leaching and seepage into surface and underground waters outside the illegal disposal of these untreated wastes into the environment.

\subsection{Sample Collection and Preparation}

Twenty one produced water samples were collected from the seven selected flow stations which includes: Ogini (PWOG), Owhe (PWOW), Evwreni (PWEV), Afiesere (PWAF), Eriemu (PWER), Otorogun (PWOT) and Olomoro- Oleh (PWOL)

At the point of sampling, 2-liter plastic container was used for the collection of the samples with about $1 \%$ air space of the container left for thermal expansion. Sample containers were raised three times with sampled produced water to minimize contamination from the original content of sample container. Produced water samples collected from the flow stations were immediately acidified with $10 \mathrm{ml} \pm 1 \mathrm{ml}$ of II MHCL per liter of samples collected to avoid absorption of radioactivity on the walls of the containers (IAEA, 2003; Tchokossa et al., 1999). The samples containers were than tightly covered with container cover and kept in the laboratory until analysis. Thereafter, samples collected were sent to the Centre for Energy Research and Development (CERD), Obafemi Awolowo University lle-lfe, Nigeria for analysis.

At the radioactivity measurement laboratory centre for energy research and development (CERD), Obafemi Amolowo University lle-ife Nigeria beaker of one (1) liter volume capacity washed, rinsed with a dilute sulfuric acid and dried to avoid contamination with the sample containers were filled with known volume of the produced water samples were firmly sealed for four weeks to ensure that loss of radon does not occur and ensuring secular equilibrium to be established before the gamma-ray analysis.

\subsection{Sample Analysis}

The samples were analyzed at CERD Gamma Ray Spectrometry Laboratory, Obafemi Amolowo University lle-ife, using a thallium activated 3"x3" Sodium iodide [NaI(TI)] detector connected to ORTEC 456 amplifier. The detector, enclosed in a $100 \mathrm{~mm}$ thick lead shield, was connected to a computer program SAMPO 90 window that matched gamma energies to a library of possible isotopes. Since the accuracy of the quantitative measurements is depended on the calibration of the spectrometry system and adequate energy. Background measurement and efficiency calibration of the system was made possible using Cs-137 and Co-60 standard sources from IAEA, Vienna. Spectrum were accumulated for background for 29000 s at 900 volts to produce strong peaks at gamma emitting energies of $1460 \mathrm{keV}$ for ${ }^{40} \mathrm{~K}$; $609 \mathrm{keV}$ of ${ }^{214} \mathrm{Bi}$ and $911 \mathrm{keV}$ of ${ }^{228} \mathrm{Ac}$, which were used to estimate the concentration of ${ }^{238} \mathrm{U}$ and ${ }^{232} \mathrm{Th}$, respectively. The energy resolution of the detector using Cs-137 and Co-60 standards is $39.5 \%$ and $22.2 \%$ respectively while the activity of the standards at the time of calibration is $25.37 \mathrm{KBq}$ for Cs- 137 and $4.84 \mathrm{KBq}$ for Co60. The background spectra, measured under the same conditions for both the standard and sample measurements, were used to correct the calculated sample activities concentration in accordance with Arogunjo et al., 2005. The activity concentration $(\mathrm{C})$ in $\mathrm{Bql}^{-1}$ of the radionuclides in the samples was calculated after subtracting decay correction using the expression:

$$
\mathrm{C}_{\mathrm{s}}=\mathrm{N}_{\mathrm{Ey}} / \varepsilon_{\mathrm{E} \gamma} \times \mathrm{M}_{\mathrm{v}} \times \mathrm{t}_{\mathrm{c}} \times \mathrm{P}_{\gamma}\left(\mathrm{Bql}^{-1}\right)
$$

Where $\mathrm{C}_{\mathrm{s}}=$ Sample concentration, $\mathrm{N}_{\mathrm{Ey}}=$ net peak area of a peak at energy, $\varepsilon_{E y}=$ Efficiency of the detector for a $\gamma$ energy of interest, $\mathrm{M}_{\mathrm{v}}=$ Sample volume, $\mathrm{t}_{\mathrm{c}}=$ total counting time, $\mathrm{P}_{\gamma}=$ Emission probability of radionuclide of interest. 


\subsection{Radiation Hazard Indices Calculation}

It is justifiable to exploit different known radiation health hazard indices analysis to arrive at a better and safer conclusion on the health status of a radiated or irradiated person and environment. To assess the radiation hazards associated with sources of water samples examined, three quantities have been defined (Zarie and Al Mugren, 2010; Agbalagba and Onoja, 2011)

\subsubsection{Radium Equivalent Activity Index $\left(R a_{e q}\right)$}

To represent the activity levels of ${ }^{226} \mathrm{Ra},{ }^{228} \mathrm{Ra}$ and ${ }^{40} \mathrm{~K}$ by a single quantity, which takes into account the radiation hazards associated with them, a common radiological Index was used (Dieb et al., 2008). This Index is called Radium Equivalent $\left(\mathrm{Ra}_{\mathrm{eq}}\right)$ activity and is mathematically defined by (UNSCEAR, 2000):

$$
\mathrm{Ra}_{\mathrm{eq}}=\mathrm{C}_{\mathrm{Ra}}+1.43 \mathrm{C}_{\mathrm{Th}}+0.077 \mathrm{C}_{\mathrm{K}}
$$

Where $\mathrm{C}_{\mathrm{Ra}}, \mathrm{C}_{\mathrm{Th}}$ and $\mathrm{C}_{\mathrm{K}}$, are the activity concentrations of ${ }^{226} \mathrm{Ra},{ }^{228} \mathrm{Ra}$ and ${ }^{40} \mathrm{~K}$ respectively.

\subsubsection{Estimation of Gamma Radiation Absorbed Doss Rate (D)}

UNSCEAR (2000) has given the dose conversion factors for converting the activity concentrations of ${ }^{238} \mathrm{U},{ }^{232} \mathrm{Th}$ and ${ }^{40} \mathrm{~K}$ into doses $\left(\mathrm{nGyh}^{-1}\right.$ per $\left.\mathrm{Bql}^{-1}\right)$ as $0.462,0.621$ and 0.0417 , respectively.

The gamma radiation population doses of those living in the area are given as:

$$
\mathrm{D}=0.462 \mathrm{~A}_{\mathrm{u}}+0.621 \mathrm{~A}_{\mathrm{Th}}+0.0417 \mathrm{~A}_{\mathrm{k}}
$$

Where $\mathrm{D}$ is the dose rate in $\mathrm{nGyh}^{-1}$ and $\mathrm{A}_{u} \mathrm{~A}_{T h}$ and $A_{k}$ are the concentrations of uranium, thorium and potassium, respectively.

\subsubsection{External Hazard Index $\left(H_{e x}\right)$}

A widely used hazard Index (reflecting the external exposure) called the External hazard index $\mathrm{H}_{\mathrm{ex}}$ is defined as follows (UNSCEAR, 2000).

$$
\mathrm{H}_{\mathrm{ex}}=\mathrm{C}_{\mathrm{Ra}} / 370+\mathrm{C}_{\mathrm{Th}} / 259+\mathrm{C}_{\mathrm{K}} / 4810
$$

\subsubsection{Internal Hazard Index $\left(H_{i n}\right)$}

In addition to external hazard index, radon and its shortlived products are also hazardous to the respiratory organs. The internal exposure to radon and its daughter progenies due to the consuming of water is quantified by the internal hazard index $\mathrm{H}_{\mathrm{in}}$, which is given by the equation

$$
\mathrm{H}_{\mathrm{in}}=\mathrm{C}_{\mathrm{Ra}} / 185+\mathrm{C}_{\mathrm{Th}} / 259+\mathrm{C}_{\mathrm{K}} / 4810
$$

The values of the indices $\left(\mathrm{H}_{\mathrm{ex}}, \mathrm{H}_{\mathrm{in}}\right)$ must be less than unity for the radiation hazard to be negligible (Diab, et al., 2008)

\subsubsection{Committed Effective Dose}

In this study, the effective dose over one year was calculated using the following relation.

$$
E=I A C \times 365
$$

Where $\mathrm{I}$ is the daily water consumption in $1 /$ day. A is the activity/l., $\mathrm{C}$ is a dose conversion factor in $\mathrm{mSv} / \mathrm{Bq}$. Dose conversion factors used to calculate the internal radiation exposure by ingestion of radionuclide by IAEA(IAEA, 2003) were considered, see table 4 while the committed effective dose is assumed to be the arithmetic summation of the effective dose of the three radionuclides measured

\section{Results and Discussion}

Table 1: Specific activity concentration of ${ }^{226} \mathrm{Ra},{ }^{228} \mathrm{Ra}$ and ${ }^{40} \mathrm{~K}$ and Radium equivalent activity (Bq/l) in Produced Water

\begin{tabular}{llllll}
\hline S/No & CODE & FLOWSTATION & K-40 & U-238 (Ra-226) & Th-232 (Ra-228) \\
\hline 1 & PWOG & OGINI A & $16.36 \pm 6.51$ & $3.11 \pm 1.23$ & $2.40 \pm 1.65$ \\
2 & PWOG & OGINI B & $9.08 \pm 4.75$ & $2.01 \pm 0.65$ & $1.15 \pm 0.07$ \\
3 & PWOG & OGINI C & $17.24 \pm 8.32$ & $6.48 \pm 3.01$ & $8.42 \pm 3.20$ \\
4 & PWOW & OWHE A & $25.53 \pm 9.56$ & $4.77 \pm 2.80$ & ND \\
5 & PWOW & OWHE B & $19.68 \pm 5.28$ & $4.20 \pm 1.60$ & $12.30 \pm 4.87$ \\
6 & PWOW & OWHE C & $57.22 \pm 13.37$ & $7.77 \pm 2.37$ & $6.31 \pm 2.53$ \\
7 & PWEV & EVWRENI A & $84.84 \pm 21.34$ & ND & $7.24 \pm 3.16$ \\
8 & PWEV & EVWRENI B & ND & ND & $2.31 \pm 1.27$ \\
9 & PWEV & EVWRENI C & ND & $3.50 \pm 1.18$ & $6.69 \pm 2.28$ \\
10 & PWAF & AFIESERE A & $63.85 \pm 14.13$ & $7.32 \pm 4.08$ & $2.17 \pm 1.38$ \\
11 & PWAF & AFIESERE B & $27.21 \pm 7.46$ & $5.11 \pm 2.24$ & $5.98 \pm 2.57$ \\
12 & PWAF & AFIESERE C & $36.69 \pm 13.14$ & $12.17 \pm 4.71$ & $7.52 \pm 2.37$ \\
13 & PWOL & OLOMORO A & $155.22 \pm 32.27$ & $13.19 \pm 5.12$ & $4.56 \pm 1.77$ \\
14 & PWOL & OLOMORO B & $53.01 \pm 19.51$ & $8.43 \pm 3.36$ & $6.12 \pm 2.09$ \\
15 & PWOL & OLOMORO C & $38.19 \pm 12.26$ & ND & $5.42 \pm 3.14$ \\
\hline
\end{tabular}




\begin{tabular}{llllll}
\hline S/No & CODE & FLOWSTATION & K-40 & U-238 (Ra-226) & Th-232 (Ra-228) \\
\hline 16 & PWER & ERIEMU A & ND & $7.13 \pm 3.18$ & $7.42 \pm 2.09$ \\
17 & PWER & ERIEMU B & $80.43 \pm 22.58$ & $3.45 \pm 1.09$ & $3.39 \pm 1.31$ \\
18 & PWER & ERIEMU C & $25.45 \pm 8.43$ & ND & $0.75 \pm 0.34$ \\
19 & PWOT & OTOROGU A & $32.09 \pm 12.27$ & $5.83 \pm 3.12$ & ND \\
20 & PWOT & OTOROGU B & $29.05 \pm 7.74$ & $6.84 \pm 2.26$ & $2.34 \pm 1.17$ \\
21 & PWOT & OTOROGU C & ND & $2.36 \pm 1.21$ & $4.45 \pm 2.19$ \\
\hline
\end{tabular}

Table 2: Mean Specific activity concentration of ${ }^{226} \mathrm{Ra},{ }^{228} \mathrm{Ra}$ and ${ }^{40} \mathrm{~K}$ and the Estimated Health Hazard indices of the Sampled Produced Water.

\begin{tabular}{|c|c|c|c|c|c|c|c|c|c|}
\hline $\mathbf{S} / \mathbf{N}$ & CODE & K-40 & $\begin{array}{l}\text { U-238 (Ra- } \\
\text { 226) }\end{array}$ & $\begin{array}{l}\text { Th-232 } \\
\text { (Ra-228) }\end{array}$ & $\begin{array}{l}\text { Radium } \\
\text { Equivqlent } \\
\operatorname{Ra}_{\mathrm{eq}}(\mathrm{Bq} / \mathrm{l})\end{array}$ & $\begin{array}{l}\text { Absorb } \\
\text { Dose Rate } \\
\text { (D) } \mathrm{mSvy}^{-} \\
1\end{array}$ & $\begin{array}{l}\text { Internal } \\
\text { hazard } \\
\text { index } \\
\left(\mathbf{H}_{\text {in }}\right) \\
\end{array}$ & $\begin{array}{l}\text { External } \\
\text { hazard } \\
\text { index }\left(\mathrm{H}_{\mathrm{ex}}\right)\end{array}$ & $\begin{array}{l}\text { Committed } \\
\text { Effective Dose } \\
\left(\mathrm{mSvyr}^{-1}\right)\end{array}$ \\
\hline 1 & PWOG & $14.23 \pm 6.53$ & $3.87 \pm 1.63$ & $3.99 \pm 1.64$ & $10.67 \pm 4.48$ & 4.858 & 0.03 & 0.04 & $2.85 \pm 0.50$ \\
\hline 2 & PWOW & $34.14 \pm 9.40$ & $5.58 \pm 2.26$ & $9.31 \pm 3.70$ & $17.03 \pm 6.51$ & 7.854 & 0.06 & 0.07 & $5.99 \pm 0.70$ \\
\hline 3 & PWEV & $84.84 \pm 21.34$ & $3.50 \pm 1.18$ & $5.14 \pm 2.24$ & $11.08 \pm 4.14$ & 5.080 & 0.05 & 0.06 & $3.70 \pm 0.50$ \\
\hline 4 & PWAF & $42.58 \pm 11.58$ & $8.20 \pm 3.68$ & $5.22 \pm 2.11$ & $18.95 \pm 7.58$ & 8.809 & 0.05 & 0.06 & $4.50 \pm 0.70$ \\
\hline 5 & PWOL & $82.14 \pm 21.35$ & $10.81 \pm 4.24$ & $5.37 \pm 2.33$ & $21.20 \pm 7.81$ & 10.088 & 0.07 & 0.08 & $5.27 \pm 0.80$ \\
\hline 6 & PWER & $52.94 \pm 15.51$ & $5.29 \pm 2.14$ & $3.85 \pm 1.25$ & $11.75 \pm 4.00$ & 5.494 & 0.04 & 0.05 & $3.26 \pm 0.60$ \\
\hline 7 & PWOT & $30.57 \pm 10.01$ & $5.01 \pm 2.20$ & $3.40 \pm 1.68$ & $9.82 \pm 4.31$ & 4.570 & 0.03 & 0.04 & $2.87 \pm 0.40$ \\
\hline \multicolumn{2}{|c|}{ AVERAGE } & $48.78 \pm 13.67$ & $6.04 \pm 2.48$ & $5.18 \pm 2.14$ & $14.36 \pm 5.55$ & 6.68 & 0.05 & 0.06 & $4.06 \pm 0.60$ \\
\hline \multicolumn{2}{|c|}{$\begin{array}{l}\text { WHO } 2008 \\
\text { STANDARD }\end{array}$} & 10 & 1.0 & 0.1 & & & 0.1 & 0.1 & 0.1 \\
\hline
\end{tabular}

Table 3: Committed Effective Dose conversion Factor (Sv/Bq) for Member of the Public (ICRP, 1997; WHO, 2003 and Ismail et al., 2009)

\begin{tabular}{|c|c|c|c|c|c|}
\hline $\mathbf{S} / \mathbf{N}$ & Radioisotope & $\begin{array}{l}\text { Infant } \leq 1 \mathrm{yr} \\
0.5 \text { litre/day }\end{array}$ & $\begin{array}{l}\text { Children 1-12yr } \\
1.0 \text { litre/day }\end{array}$ & $\begin{array}{l}\text { Teenager } 12-17 \mathrm{yr} \\
2.0 \text { litres/day }\end{array}$ & $\begin{array}{l}\text { Adult } 17 \mathrm{yr} \\
2.0 \text { litres/day }\end{array}$ \\
\hline 1 & ${ }^{226} \mathrm{Ra}$ & $4.7 \mathrm{E}-06$ & $6.2 \mathrm{E}-07$ & $1.5 \mathrm{E}-06$ & $2.8 \mathrm{E}-07$ \\
\hline 2 & ${ }^{228} \mathrm{Ra}$ & $3.0 \mathrm{E}-05$ & $3.4 \mathrm{E}-06$ & $5.3 \mathrm{E}-06$ & $6.9 \mathrm{E}-07$ \\
\hline 3 & ${ }^{40} \mathrm{~K}$ & $6.2 \mathrm{E}-08$ & $2.1 \mathrm{E}-08$ & 7.6E-09 & $6.2 \mathrm{E}-09$ \\
\hline
\end{tabular}

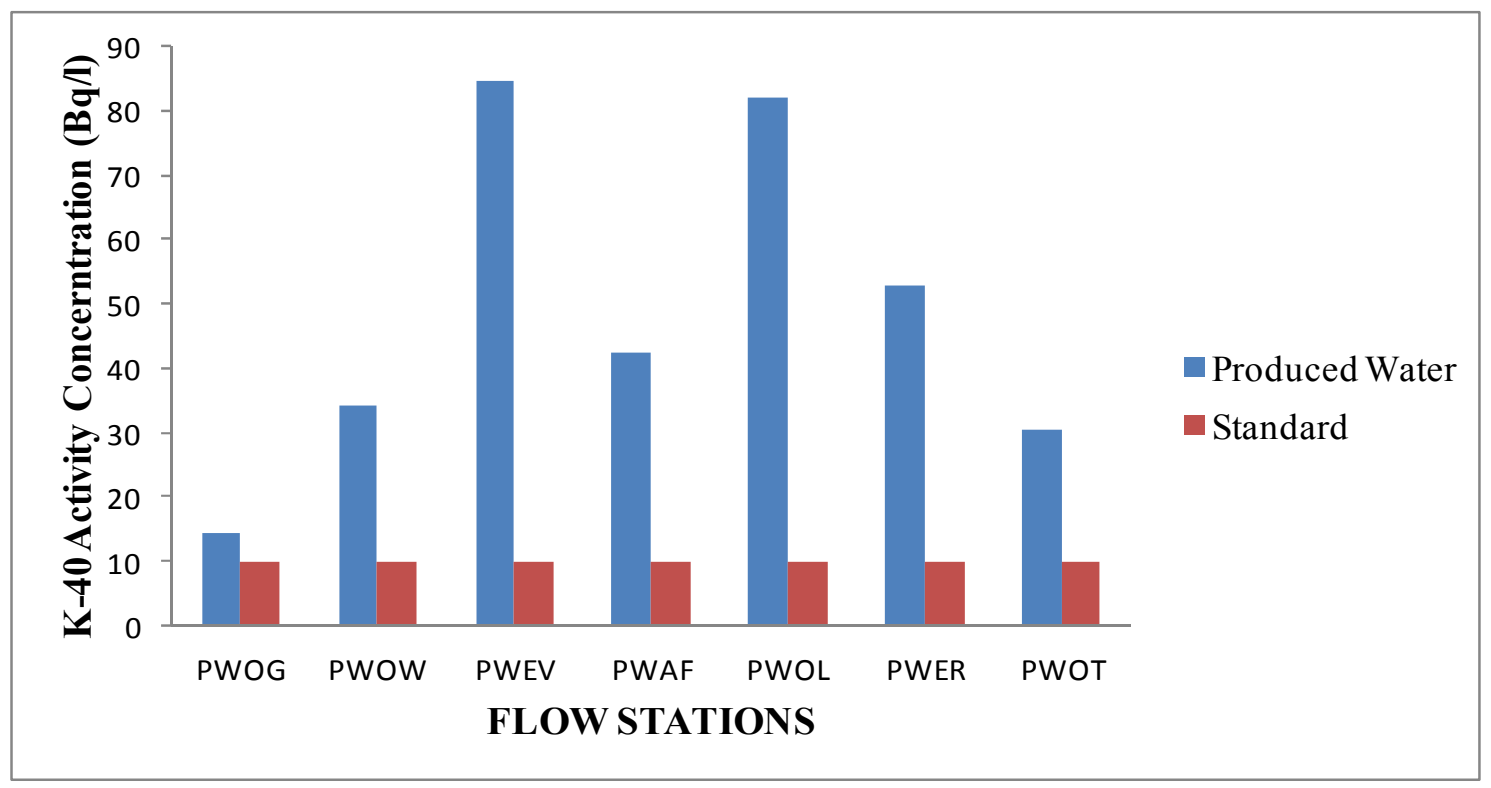

Fig. 1: Bar chart showing comparison of ${ }^{40} k$ activity concentration $\left(B q l^{-1}\right)$ with standard. 


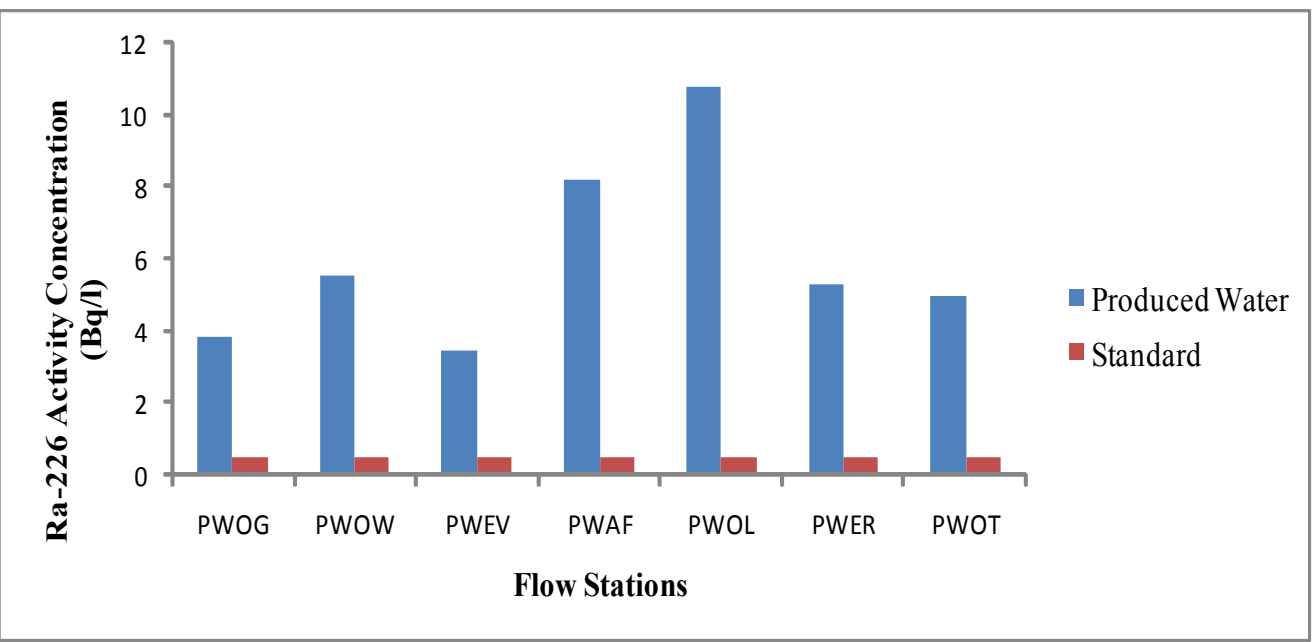

Fig. 2: Comparison of ${ }^{226}$ Ra activity concentration $\left(B q l^{-1}\right)$ with standard.

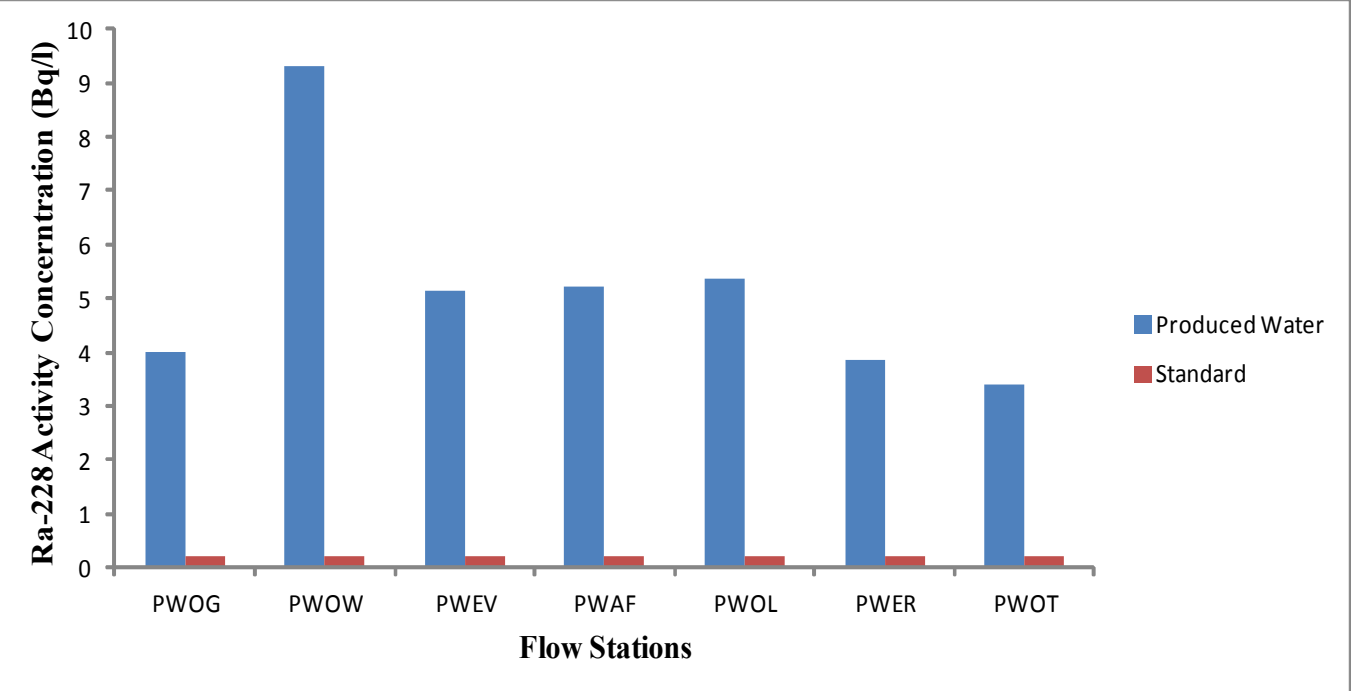

Fig. 3: Comparison of ${ }^{228}$ Ra activity concentration $\left(B q l^{-1}\right)$ with standard

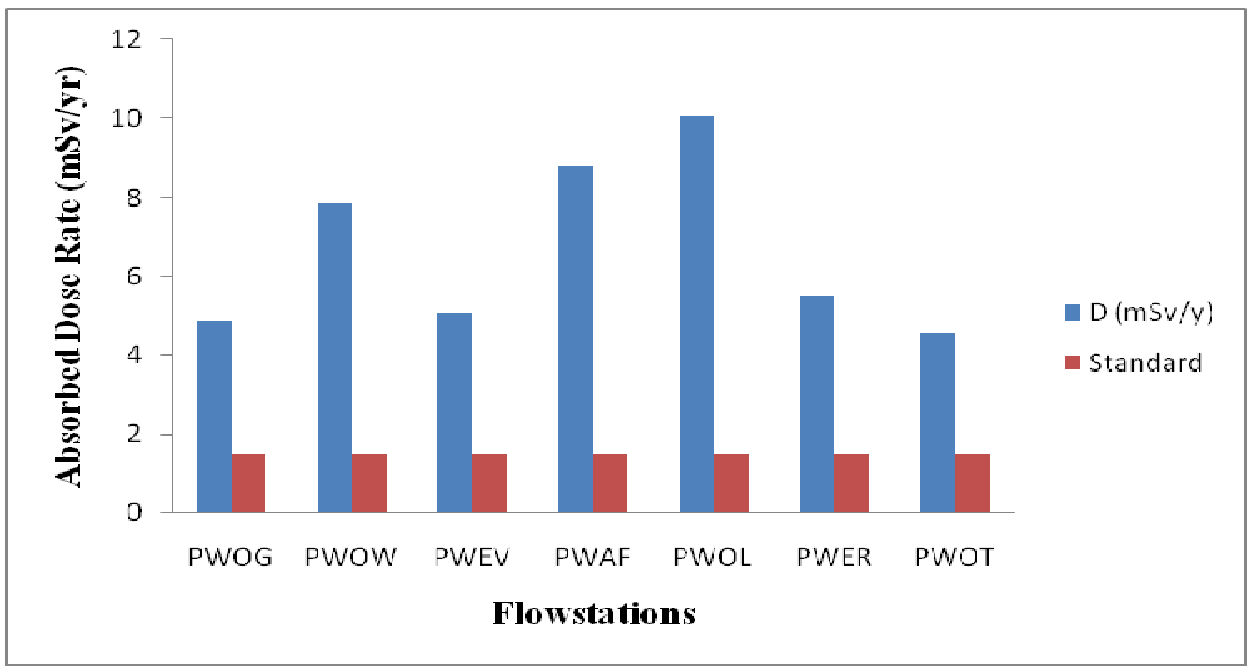

Fig. 4: Comparison of Absorbed Dose rate in the Flow Stations $\left(\mathrm{mSvy}^{-1}\right)$ with standard 


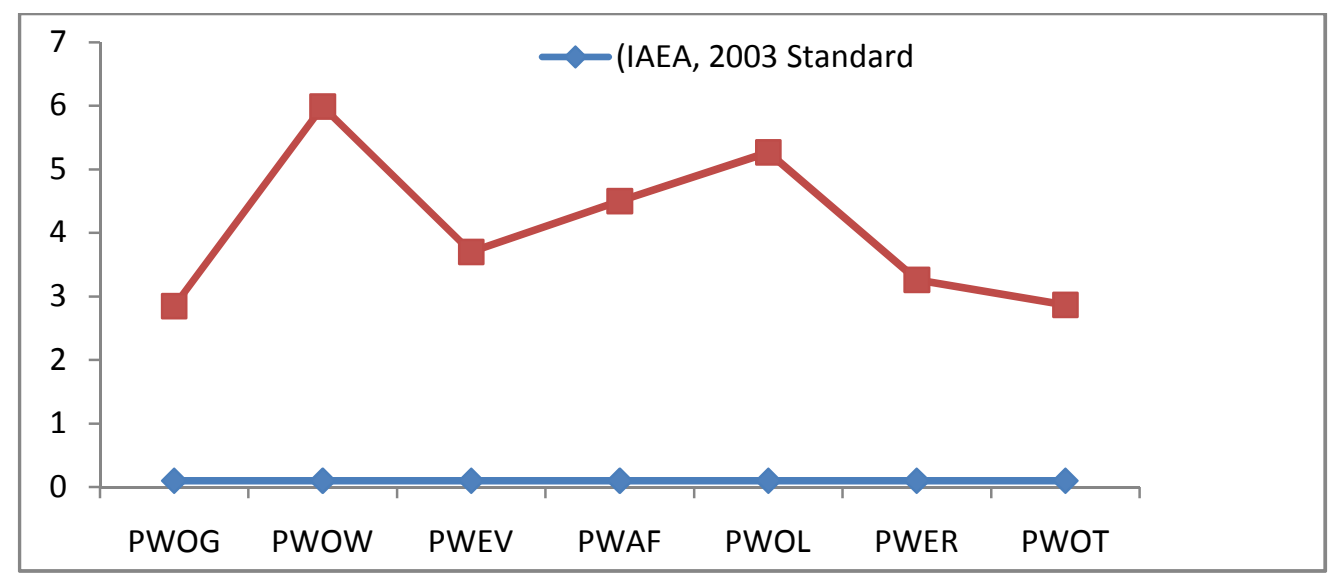

Fig 5: Comparison of Estimated Committed Effective Dose Rate with IAEA Standard

Three naturally occurring radionuclides ${ }^{40} \mathrm{~K},{ }^{226} \mathrm{Ra}$ and ${ }^{228} \mathrm{Ra}$ were determined in all the produced water samples measured and the results are shown in Tables 1 and 2. The average activity concentration of ${ }^{40} \mathrm{~K},{ }^{226} \mathrm{Ra}$ and ${ }^{228} \mathrm{Ra}$ in produced water from the studied area are $48.78 \pm 13.67 \mathrm{Bql}^{-}$ ${ }^{1}, 6.04 \pm 2.48 \mathrm{Bql}^{-1}$ and $5.18 \pm 2.14 \mathrm{Bql}^{-1}$ respectively. The largest contribution of the overall activity concentration in all the various produced water samples come mainly form ${ }^{40} \mathrm{~K}$ with the lowest concentration of $9.08 \pm 4.75 \mathrm{Bql}^{-1}$ and the highest concentration being $155.2 \pm 32.27 \mathrm{Bql}^{-1}$. This relatively higher concentration of ${ }^{40} \mathrm{~K}$ can be attributed to the presence of clay that characterized the formation in the Niger Delta and its abundance in the earth crust (Ajayi et al., 2009; Tchokossa et al., 1999). The specific activity concentration due to ${ }^{228} \mathrm{Ra}$ is relatively low in all the produced water samples investigated compared to ${ }^{226} \mathrm{Ra}$, this is because ${ }^{226} \mathrm{Ra}$ is more mobile than ${ }^{228} \mathrm{Ra}$ (NCRP, 1987). The obtained average values exceeded the (WHO, 2008) standard values limit of $10 \mathrm{Bql}^{-1}, 1.0 \mathrm{Bql}^{-1}$ and $0.1 \mathrm{Bql}^{-}$ ${ }^{1}$ for ${ }^{40} \mathrm{~K},{ }^{226} \mathrm{Ra}$ and ${ }^{228} \mathrm{Ra}$ respectively, these are clearly shown graphically in figures 1-3. These obtained activities concentration of ${ }^{226} \mathrm{Ra}$ and ${ }^{228} \mathrm{Ra}$ are higher than those reported value by Jerez Vegueira et al., (2002) in Brazil produced water, Gafvert et al., (2004) in Norway produced water and that reported by Strand et al., (1997) also in Norway. This high activity concentration may be attributed the geological formation of the areas. It can also be as a result of the drilling chemical (drilling mud), well logging equipments and other industrial radiography etc, used during oil and gas exploration, exploitation and production by the companies. The activity concentration $49.0 \mathrm{~Bq}^{-1}$ for ${ }^{40} \mathrm{~K}$ reported by Tchokossa 1999 in a previous work in Delta State, agrees with the obtained ${ }^{40} \mathrm{~K}$ activity concentration.

Table 2 shows the mean radium equivalent, absorb dose rate, internal and external hazard indices and the committed effective dose calculated from activity concentration of ${ }^{40} \mathrm{~K}$, ${ }^{226} \mathrm{Ra}$ and ${ }^{228} \mathrm{Ra}$ using equations $2-6$. The radium equivalent have its highest concentration value $21.20 \pm 7.81 \mathrm{Bql}^{-1}$ at Olomoro flow station and lowest concentration of $9.82 \pm$ $4.31 \mathrm{Bql}^{-1}$ at Otorogu gas plant with average value is 14.36 $\pm 5.55 \mathrm{Bql}^{-1}$. The absorbed dose rate Olomoro flow station has the highest value $10.088 \mathrm{mSvy}^{-1}$ while Otorogu gas plant has the lowest value $4.570 \mathrm{mSvy}^{-1}$ with an average value of $6.679 \mathrm{mSvy}^{-1}$. The obtained results when compared with standard of $1.5 \mathrm{mSvy}^{-1}$ (UNSCEAR 2000) as shown in Fig 4, revealed that the average values of absorbed dose rate in all the produced water samples are higher than world standard limit. This could again be attributed to geology formation of the study area and the various radionuclide induce activities of the exploration companies. These obtained values are higher than that reported by Ajayi et al., 2009) in drilled and hand dug well drinking water in Abeokuta, Ogun State and those reported by Yussuf et al., (2012) in drinking and mineral water in Johor Bahru, Malaysia. But these obtained values are lower than the values reported by Vesterbacka (2007) in drinking water in Finland.

The value of the internal hazard index ranged from 0.03 to 0.07 with an average value of 0.05 , while the external hazard index ranged from 0.04 to 0.08 with an average value of 0.06 . These indices of predicting the hazard level of human is still within the recommended limits.

Radionuclide may reach the gastrointestinal tract directly by ingestion or indirectly by transfer from the respiratory tract. From the small intestine the radionuclide can be absorbed to the body fluid. The effective dose due to water intake by adults and consequently the committed effective dose are calculated using equation 6 and table 3 as extracted from ICRP Publication 78 (ICRP, 1997). On the average, adults are considered to consume 2litres of water per day. This is a conservative estimation in summer in Nigeria. The average committed effective dose rate in produced water from crude oil ranged from $2.85 \pm 0.50$ $\mathrm{mSvy}^{-1}$ in Ogini flow station produced water to $5.27 \pm 0.80$ $\mathrm{mSvy}^{-1}$ in Oleh- Olomoro flow station produced water with mean value of $4.06 \pm 0.60 \mathrm{mSvy}^{-1}$. The values obtained are in consonant with the reported values by Agbalagba et al., 2013. However, they are well above the allowed dose contributed from water which is estimated to be $0.1 \mathrm{mSvy}^{-1}$ (WHO, 2003; Ismail et al., 2002). 


\section{Conclusion}

The concentration of natural radioactive series nuclides have been shown to vary from one oil field to another. The relatively high radionuclide activity concentration in most produced water over world standard average values and above values obtained in other parts of the world is attributed to the impact of oil and gas exploration and exploitation activities on the environment. This could result from contamination of aquifers, precipitation of radon daughters and effluent discharge at various magnitudes in the oil fields. The estimated committed effective dose if consumed by the public are well above their permissible limits. Therefore, the produced waters in these oil fields are highly contaminated radiologically. Though when discharged into underground or surface drinking water bodies, immediate health implication for the public users may not be observed at the present level, but long term accumulative health side-effects are highly probable in the host community, thus proper treatment of the water is highly recommended before discharge into water bodies. This work will add to the world data base of natural radionuclide in produced water from crude oil.

\section{References}

[1] Abbady A.G.E. 2004. Estimation of Radiation Hazard Indices from Sedimentary Rocks in Upper Egypt. Applied Radiation and Isotopes, 60: 111-114.

[2] Agbalagba E.O. and Onoja R.A., 2011. Evaluation of natural radioactivity in soil, sediment and water samples of Niger delta (Biseni) flood plain lakes, Nigeria. J. Environ. Rad. 102: $667-671$

[3] Agbalagba, E.O., Avwiri, G.O. and Ononugbo, P.C. 2013. Activity concentration and radiological impact assessment of ${ }^{226} \mathrm{Ra},{ }^{228} \mathrm{Ra}$ and ${ }^{40} \mathrm{~K}$ in drinking waters from (OML) 30, 58 and 61 oil fields and host communities in Niger Delta region of Nigeria. Elsevier; Journal of Environmental Radioactivity116:197-200

[4] Ajayi O.S, and Achuka J (2009). Radioactivity in drilled and dug well drinking water of Ogun State Southwestern Nigeria and consequentdose estimates. Rad. Prot. Dos., 135(1) 5463.

[5] Arogunjo, A.M., Ofuga, E.E. and Afolabi, M.A., 2005. Levels of natural radionuclides in some Nigerian cereals and tubers. J. Environ. Rad. 82:1- 6

[6] Avwiri, G.O. and Agbalagba, E.O. 2012. Studies on the radiological impact of oil and gas activities in Oil Mineral Lease 30 (OML3) oil fields in Delta State, Nigeria. J. Pet. Environ Biotechnol. 3(2): 1- 8.

[7] Beretka, I., Mathew, P.I., (1985). Natural radioactivity of Australian building materials, waste and by-products. Health Physics 48, 87-95.

[8] Chowdhurry, S., Husian, T., Veiteh, H., Bose, N. adna Sadiq, R., (2004): Human Health Risk Assessment of Naturally Occurring Radioactivity Materials in Produced Water, Canada.
[9] Diab, H. M., S.A. Nouh, A. Hamdy and S.A. El- Fiki, 2008. Evaluation of natural radioactivity in a cultivated area around a fertilizer factory. J. Nucl. and Rad. Phys. 3(1): 5362.

[10] Gafvert.T and Faerevik.I. 2004: Natural Radioactivity in Produced Water from Norwegian Oil and Gas Industry in 2003.

[11] IAEA (International Atomic Energy Agency), 2003. International Basic Safety Standards for protection against ionizing radiation and for the safety of radiation sources. No 115, (IAEA, Vienna 2003).

[12] ICRP (International Commission on Radiological Protection), 1997. ICRP Publication 78; Individual Monitoring for Internal Exposure of workers

[13] Isam-Salih, M.M., Pettersson, H.B. and Lund, E., 2002. Uranium and thorium series radionuclides in drinking water from drilled bedrock wells: correlation to geology and bedrock radioactivity and dose estimation. Radiat. Protect Dosim., 102(3), 249-258.

[14] Isehunwa S. O. and Onovae S., 2011. Evaluation of produced water discharge in the Niger-Delta. ARPN Journal of Engineering and Applied Sciences. VOL. 6, NO. 8, pg 66- 72. www.arpnjournals.com

[15] Ismail A.M., Kullab M.K. and Saq'an S.A, 2009. Natural radionuclides in bottled drinking water in Jordan and their committed effective doses. Jordan J. Phy.2(1):47-57

[16] Jerez Vegueria SF, Godoy JM, Miekeley N. 2002. Environmental impact studies of barium and radium discharges by produced water from the "Bacia de Campos" oil-field offshore platforms, Brazil. Journal of Environmental Radioactivity 2002; 62: 29-38.

[17] Neff JM (2002). Bioaccumulation in Marine Organisms; Effects of Contaminants from Oil Well Produced Water. pp Elsevier Science Ltd. Kidlington, Oxford, UK. pp 191-202.

[18] SPDC, EIA, 2004. Environmental impact assessment of Afiesere, Eriemu, Repele and Uzere for oil field development. Scooping workshop for EIA process, May 2004; pg 2-6.

[19] Strand T, Lysebo I, Kristensen D, Birovljev A., 1997. Deposits of naturally occurring radioactivity in production of oil and natural gas. NRPA report. Østerås, Norwegian Radiation Protection Authority Norwegian.

[20] Taiwo, B.A, and Akalia, T.C., 2009. Spatial variation in groundwater geochemistry and water quality index in Port Harcourt. Rivers State, Nigeria Scientia Africana 8(1): 134155

[21] Tchokossa P, Olomo,J.B and Balogun, F.A., 2011. Assessment of Radionuclide Concentrations and Absorbed Dose from Consumption of Community Water Supplies in Oil and Gas Producing Areas in Delta State, Nigeria. World Journal of Nuclear Science and Technology, 1, 77-86

[22] Tchokosse, P., Olomo, J.B. and Osibota, O.A., 1999. Radioactivity in the community water supplies of Ife-central and Ife-East L.G.A.'S Osun State, Nigeria. Nucl. Instr. and Methods in Phys. Res. (A422:780-784).

[23] United Nations Scientific Committee on the Effects of Atomic Radiation (UNSCEAR), 2000. Sources and 
effects of ionizing radiation (Report to the General Assembly), New York: United Nation.

[24] UNSCEAR, 2000. Sources and Effects of Ionizing Radiation. United Nations Scientific Committee on the Effects of Atomic Radiation, United Nations, New York.

[25] Vegueria SFJ, Godoy JM and Miekeley N (2002). Environmental Impact in Sediments and Seawater due to Discharges of $\mathrm{Ba},{ }^{226} \mathrm{Ra},{ }^{228} \mathrm{Ra}, \mathrm{V}, \mathrm{Ni}$, and $\mathrm{Pb}$ by Produced Water from the Bacia de Campos Oil Field Offshore Platforms; Environmental Forensics 3:115-123.

[26] Vesterbacka Pia, 2007. Natural radioactivity in drinking water in Finland. Boreal Environ. Res. 12:11-16
[27] WHO, 2003. Guidelines for drinking water quality. Third ed., Radiological quality of drinking water, World Health Organization, Geneva, Switzerland.

[28] World Health Organization (WHO), 2008. Guidelines for drinking water policy $3^{\text {rd }}$ ed., Incorporating the $1^{\text {st }}$ and $2^{\text {nd }}$ agenda, Vol.1 recommendation. WHO Geneva, Switzerland.

[29] Yusuf N.M., Hossian I. and Wagiran H., 2012. Natural radioactivity in drinking and Mineral Water. Scientific Research and Essays Vol. 7(9) pg. 1070-1075.

[30] Zarie, K.A. and K.S. Al Mugren, 2010. Measurement of natural radioactivity and assessment of radiation hazard in soil samples from Tayma area (KSA). Isotope and Rad. Res. 42(1):1-9. 